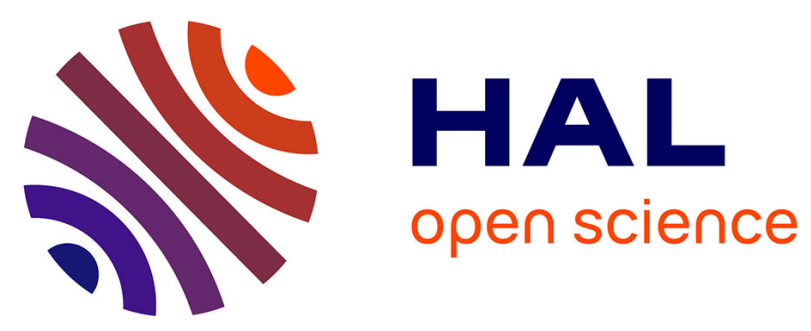

\title{
Corinth terraces re-visited: Improved paleoshoreline determination using Pleiades-DEMs
}

De Gelder, D Fernández-Blanco, R Lacassin, R Armijo, A Delorme, J Jara-Muñoz, D. Melnick

\section{- To cite this version:}

De Gelder, D Fernández-Blanco, R Lacassin, R Armijo, A Delorme, et al.. Corinth terraces re-visited: Improved paleoshoreline determination using Pleiades-DEMs. DRT : 20th International Conference on DEFORMATION MECHANISMS, RHEOLOGY \& TECTONICS, Sep 2015, Aachen, Germany. pp.12-14, 10.1127/1864-5658/2015-06 . insu-01176308

\section{HAL Id: insu-01176308 \\ https://hal-insu.archives-ouvertes.fr/insu-01176308}

Submitted on 8 Oct 2015

HAL is a multi-disciplinary open access archive for the deposit and dissemination of scientific research documents, whether they are published or not. The documents may come from teaching and research institutions in France or abroad, or from public or private research centers.
L'archive ouverte pluridisciplinaire HAL, est destinée au dépôt et à la diffusion de documents scientifiques de niveau recherche, publiés ou non, émanant des établissements d'enseignement et de recherche français ou étrangers, des laboratoires publics ou privés. 


\section{Corinth terraces re-visited: Improved paleoshoreline determination using Pleiades-DEMs}

De Gelder, G. ${ }^{1}$, Fernández-Blanco, D. ${ }^{1}$, Lacassin, R. ${ }^{1}$, Armijo, R. ${ }^{1}$, Delorme, A. ', Jara-Muñoz, J. ${ }^{2}$, Melnick, D. ${ }^{2}$

1 Tectonique et Mécanique de la Lithosphère, Institut de Physique du Globe de Paris, Sorbonne Paris Cité, Univ. Paris Diderot, UMR 7154 CNRS, F-75005 Paris, France

2 Institut für Erd- und Umweltwissenschaften, Universität Potsdam, 14476 Potsdam, Germany

The newest generation of satellites have greatly improved the capabilities of optical imagery over the last decade (e.g. Bernard et al. 2012). Ground resolution has increased by one order of magnitude (to sub-metric pixel images), and improved sensors allow images to be located with an absolute accuracy of within a few meters. Better-resolved images facilitate refined tectonic studies of faults, basins, terraces, and other geomorphic features as it provides the opportunity to extract detailed topographic information.

We have developed high-resolution digital elevation models (DEMs) in eight locations in Greece (e.g. Fig.1) from tri-stereo satellite images acquired by the new Pleiades platform of CNES. Using the opensource Orfeo ToolBox we created tie-points for the $0.5 \mathrm{~m} / \mathrm{pixel}$ images that were then oriented with Euclidium software. Finally, we used Mic-Mac opensource software to convert the images to DEMs. With $0.5 \mathrm{~m}$ resolution, these DEMs are state-of-the-art in comparison to previous DEMs made from satellite imagery (Fig.2).

In this study we explore the potential of one of these DEMs, in the eastern Gulf of Corinth, for the analysis of a flight of marine terraces (Fig.1). Favourable conditions for terrace formation including a very high surface uplift rate $(1-2 \mathrm{~mm} / \mathrm{yr})$

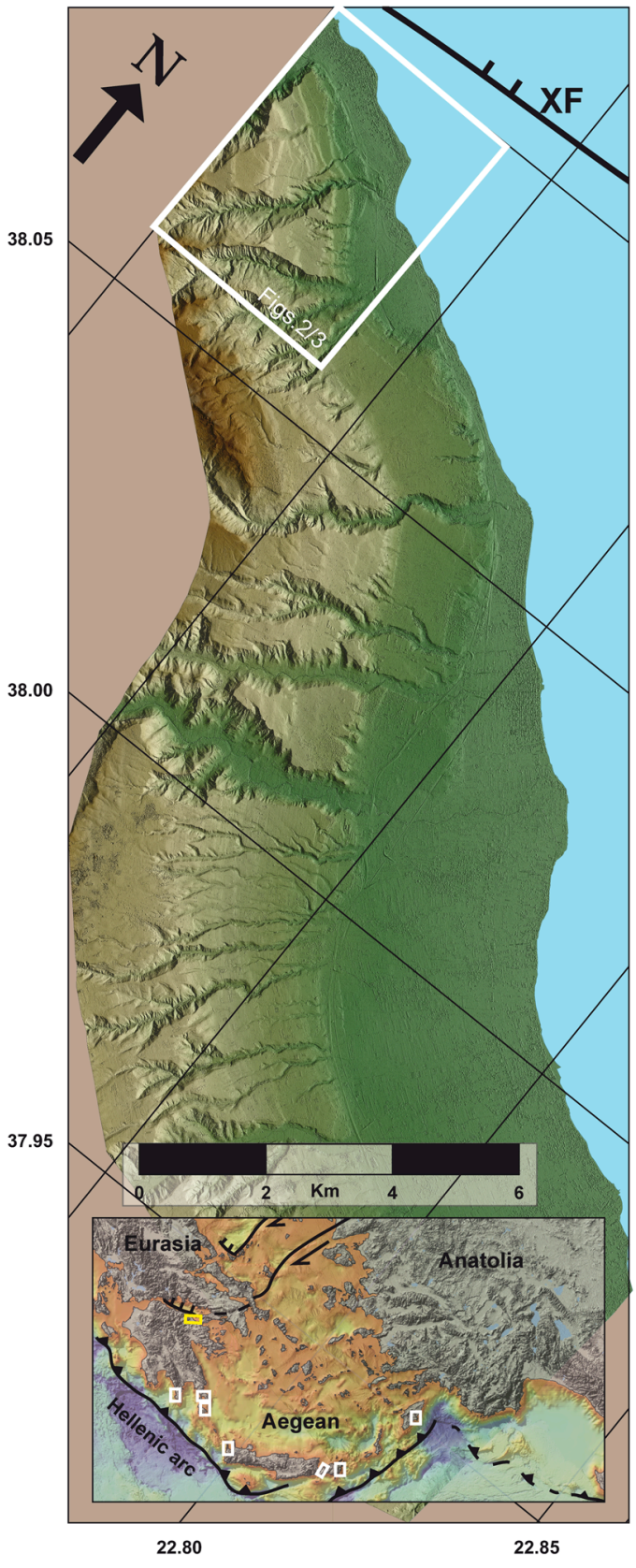

Figure 1 : Hillshade image for the flight of marine terraces in the Eastern Gulf of Corinth. $\mathrm{XF}=$ Xylokastro Fault. Inset shows overall tectonic setting and locations of high-resolution DEMs (white, Corinth in yellow) 
due to the nearby Xylokastro Fault - have resulted in one of the most extensive and well-preserved terrace sequences in Greece. The location is ideal to test the quality of our data and methodology since the terraces have been well-studied before (e.g. Armijo et al. 1996).

The high quality of these $0.5 \mathrm{~m}$-resolution DEMs allows the detection of vegetation, crops and man-made structures. However, these represent 'noise' for the accurate detection of terraces, so we prefer downsampled images with $2 \mathrm{~m}$ resolution. We mapped the terraces using the surface classification model (SCM) of Bowles and Cowgill (2012), and a combination of satellite and hillshade images, slope maps and topographic profiles derived from the DEMs.

We tested three different methods to determine the elevation of the paleoshorelines using TerraceM (JaraMuñoz et al. 2015), a graphical user interface in MATLAB $®$ for the analysis of swath profiles. Since our satellite-based DEMs include vegetation and especially around the lower levels there are many man-made structures, minimum topography swath profiles seem the most appropriate, as long as they are located away from river valleys to avoid fluvial overprints. Determining the slope of the uneroded cliffs is essential for two of the applied methods. As such, we analysed 60 swath profiles of the 4 lowest terrace levels, which are 100ky and younger (Armijo et al., 1996), and are located at the area of the DEM where the surface uplift rate has been the highest $(\sim 1.5 \mathrm{~mm} / \mathrm{yr}$; Armijo et al. 1996). We find an average slope of $41 \pm 10$ degrees for all the levels (Fig.3f), fitting with field observations of cliffs unaltered by roads and houses.

The first method, the "classic" analysis (Fig.3c), involves picking two points on undisturbed areas belonging to the paleocliff and the paleoplatform. The pickings are fitted by linear regression with $95 \%$ confidence intervals, and their intersection marks the shoreline angle. The second method, the diffusion analysis (Fig.3d), is based on the principle that mass transport due to erosional processes occurs in the downslope direction and in a proportional rate to the local topographic gradient (Hanks et al., 1984). By picking the lowest uneroded point on the upper terrace and two points on the paleoplatform, as well as setting the slope of the

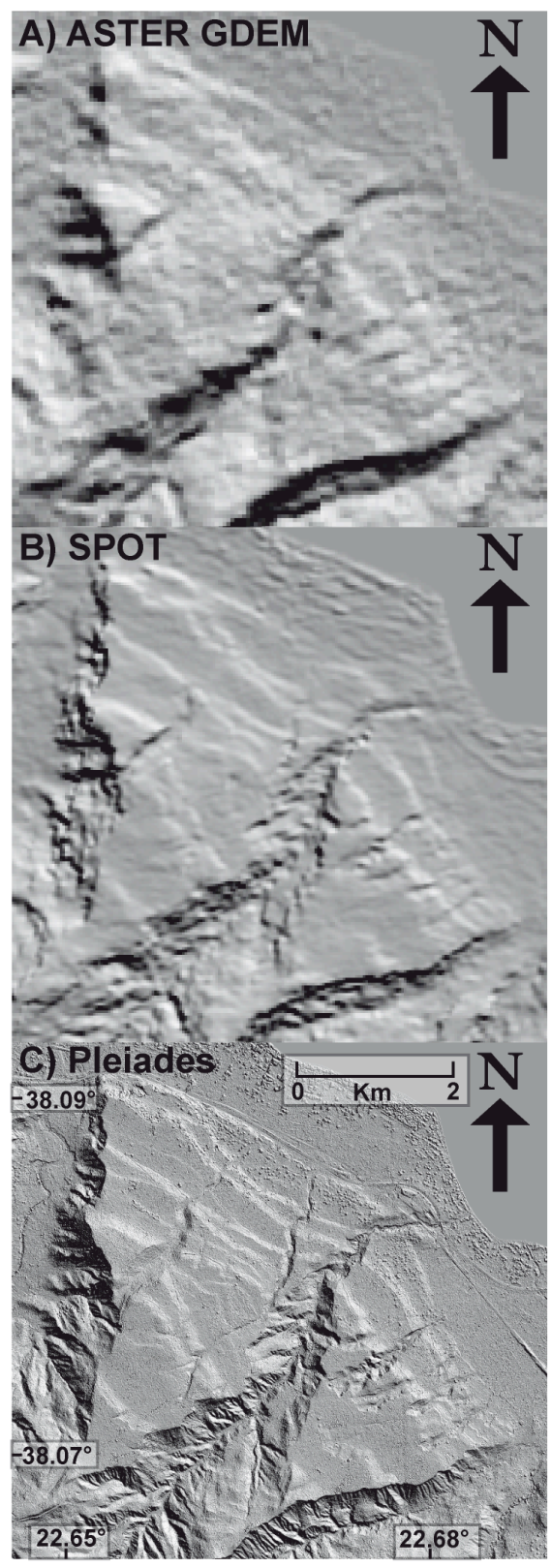

Figure 2: Comparison of hillshade images from an ASTER DEM (30m resolution), SPOT DEM (20m resolution) and Pleiades DEM (2m resolution), for our selected site in the Eastern Gulf of Corinth 

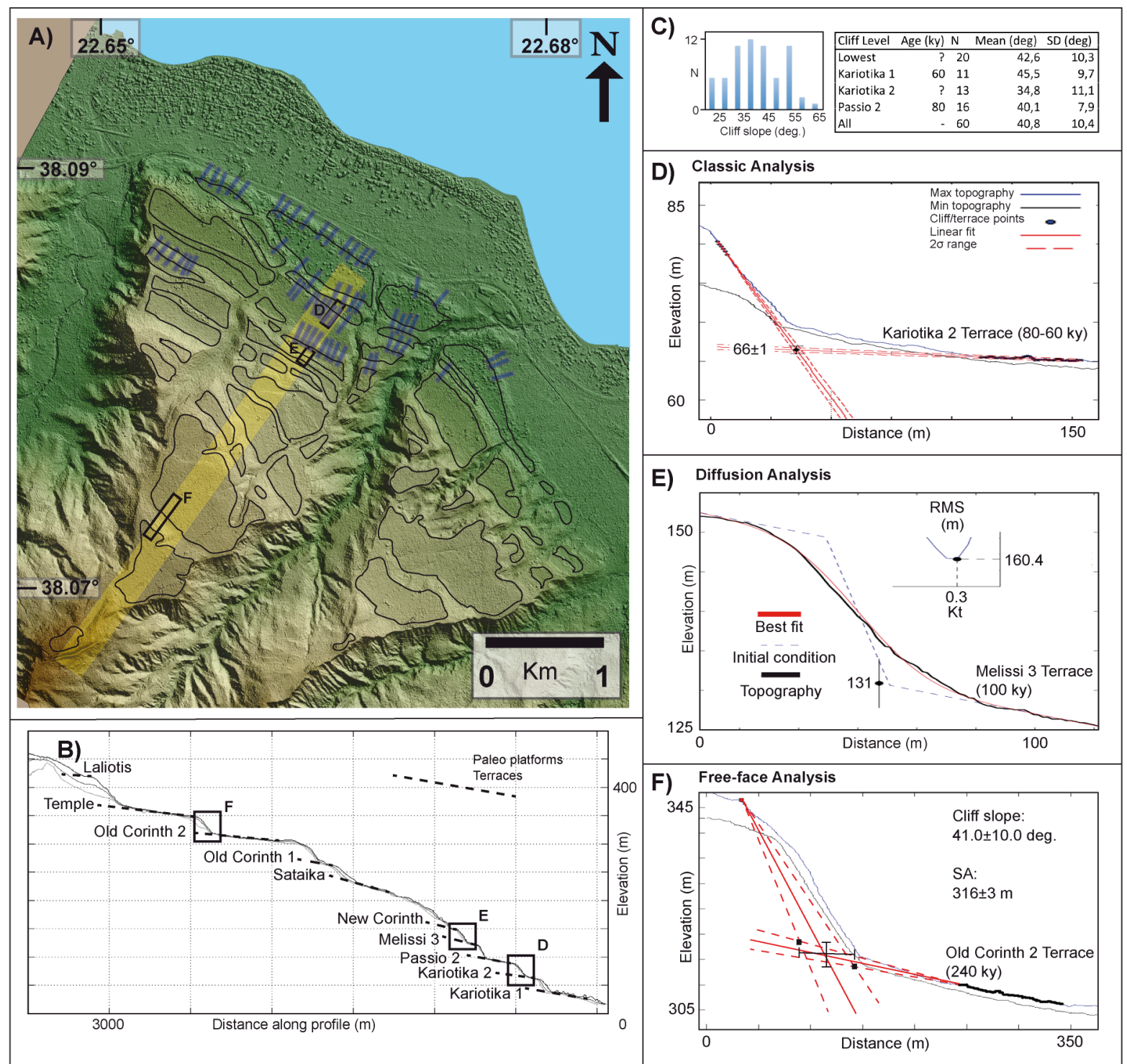

Figure 3 : Detail of the terrace analysis on the Corinth DEM. A) Hillshade image, with the blue swath profiles indicating the cliffs used to determine the cliff slopes for the $<100 \mathrm{ky}$ terraces (see $\mathrm{C}$ ), and the yellow swath profile indicating the location for the profile in B) C) Statistical results on the analysis of $<100 \mathrm{ky}$ cliff slopes D) Classic analysis in TerraceM E) Diffusion analysis in TerraceM F) Free-face analysis in TerraceM

paleocliff and the diffusion parameters, we obtain both an inner shoreline angle, and a geomorphic age with RMS misfit (Avouac, 1993). The third method, the free-face analysis (Fig.3e), uses the slope of the most recent cliffs -including error margin- as an indicator of the paleocliff slope. Picking a point for the paleocliff and two for the paleoplatform provides a range of possible slopes, resulting in a range of shoreline angles. 
The detailed comparison of the three methods provided here allows us to infer that the classic analysis, although straightforward and easy to apply, is only appropriate if we are certain that the paleocliff is undisturbed. The diffusion analysis is very sensitive to the diffusion rate and cliff slope parameters, and the geometries of many cliffs do not seem to match with the simplified diffusion process. Therefore, we consider that, for most cases, the best way to provide an honest range of possible shoreline angles is to define two extreme options for a maximum and a minimum estimate. The maximum can then be defined through the free-face analysis and the minimum should be close to the inner edge of the terrace (Fig.3c).

The shoreline angle is generally considered to be a good approximation for the paleoshoreline, usually with an uncertainty of a few meters depending on factors such as tide regime and erosion during extreme weather events (e.g. Jardine 1981). DEMs provide us with the opportunity to check these lateral variations in detail, and try to distinguish relative contributions from climatic and tectonic processes. In terms of tectonic activity, the Corinth Rift is one of the fastest extending regions in the world, of which the Xylokastro Fault and the uplifted terraces are a major expression (Armijo et al., 1996). With the quality of the Pleiades DEMs we are no longer limited by resolution and accuracy of the topographic information, since uncertainties in the relative contributions of erosion, climate, and tectonics now outweigh those in the data itself, providing an encouraging opportunity to re-evaluate the area.

The quality of the Corinth DEM in combination with the TerraceM interface allows us to (locally) detect more terrace sub-levels compared to previous studies, and improve our constraints in finding the paleoshorelines. Apart from terrace analysis, possible future applications of these Pleiades DEMs -both in Corinth and in other locations- include the analyses of (active) faults, river drainages and sedimentary basins, all of which can greatly benefit from this new generation of high-quality topographic data.

Acknowledgements : This work is supported by the European Marie-Curie project ALErT (Grant FP7-PEOPLE2013-ITN number 607996) and by the ISIS program of CNES.

References :

Armijo, R., Meyer, B., King, G. C. P., Rigo, A., \& Papanastaaiou, D. (1996). Quaternary evolution of the Corith Rift and its implications for the Late Cenozoic evolution of the Aegean. Geophys. J. Int., 126, 11-53.

Avouac, J.-P. (1993). Analysis of Scarp Profiles: Evaluation of Errors in Morphologic Dating. J. Geophys. Res., 98(B4), 6745-6754.

Bernard, M., Decluseau, D., Gabet, L., \& Nonin, P. (2012). 3D Capabilities of Pleiades Satellite. Int. Arch . Photogramm. Rem. Sens. Spatial Inform. Sci., XXXIX-B3(September), 553-557.

Bowles, C. J., \& Cowgill, E. (2012). Discovering marine terraces using airborne LiDAR along the MendocinoSonoma coast , northern California. Geosphere, 8(2), 386-402. doi:10.1130/GES00702.1

Hanks, T. C., Bucknam, R. C., Lajoie, K. R., \& Wallace, R. E. (1984). Modification of wave-cut and faultingcontrolled landforms. J. Geophys. Res., 89(B7), 5771. doi:10.1029/JB089iB07p05771

Jara-Muñoz, J., Melnick, D., Brill, D., \& Strecker, M. R. (2015). Segmentation of the 2010 Maule Chile earthquake rupture from a joint analysis of uplifted marine terraces and seismic-cycle deformation patterns. Quaternary Sci.Rev., 113, 171-192. doi:10.1016/j.quascirev.2015.01.005

Jardine , W.G. (1981). The determination of former shoreline positions in areas of large tidal range, with examples taken mainly from Scotland. Bull. Assoc. Fr. Étude Quaternaire., 18, 67-70. 